\title{
On the selection of financing instruments to push the development of new technologies: Application to clean energy technologies
}

\author{
Luis Olmos ${ }^{a, b}$ \\ Sophia Ruester ${ }^{b}$ \\ Siok-Jen Liong ${ }^{b}$ \\ a Instituto de Investigación Tecnológica, Universidad Pontificia Comillas, Santa Cruz de Marcenado, 26. 28015 \\ Madrid, Spain \\ ${ }^{\mathrm{b}}$ European University Institute, Via dei Roccettini 9, I-50014 San Domenico di Fiesole (FI), Fiesole, Italy
}

Corresponding author at. Instituto de Investigación Tecnológica, Universidad Pontificia Comillas, Santa Cruz de Marcenado, 26, 28015 Madrid, Spain. Tel.: +34 91540 6260; fax: +34 915423176.

Published in Energy Policy, Volume 43, 2012, pp. 252-266.

\begin{abstract}
Achieving climate policy goals requires mobilizing public funds to bring still immature clean technologies to competitiveness and create new technological options. The format of direct public support must be tailored to the characteristics of technologies addressed. Based on the experience accumulated with innovation programs, we have identified those features of innovation that should directly condition the choice of direct support instruments. These include the funding gap between the cost of innovation activities and the amount of private funds leveraged; the ability of technologies targeted to compete for public funds in the market; the probability that these technologies fail to reach the market; and the type of entity best suited to conduct these activities.

Clean innovation features are matched to those of direct support instruments to provide recommendations on the use to be made of each type of instrument. Given the large financing gap of most clean energy innovation projects, public grants and contracts should finance a large part of clean pre-deployment innovation. However, public loans, equity investments, prizes and tax credits or rebates can successfully support certain innovation processes at a lower public cost. Principles derived are applied to identify the instrument best suited to a case example.
\end{abstract}




\section{Introduction}

This article provides guidelines for the selection of policy instruments directly mobilizing public funds to push the development of new technologies. These general guidelines are then used to provide specific recommendations for clean energy technologies. The focus of our analysis is on the support of pre-deployment innovation, i.e., the first and highly risky stage of the innovation chain. "Getting the market prices right" is necessary to trigger clean energy innovation, as argued by Popp (2002). However, this alone will not result in an adequate and efficient transition to a low-carbon (low-C) economy, see Foxon (2003). It is actually a combination of technology push policies and demand pull ones which could succeed in avoiding serious climate damage at an affordable cost. According to Arrow (1962), two main factors are responsible for the reduction observed in the level of privately financed clean Research, Development, and Demonstration (RD\&D) activities below optimal levels:

- The existing limits to the share of market revenues from the exploitation of new technologies that innovators can appropriate (which, as explained below, may be especially low for clean innovation);

- and the unwillingness of the latter to bear innovation risks.

Other barriers to achieving an optimal level of innovation delivered by the market are the externalities not properly addressed (like the environmental one created by Green House Gas (GHG) emissions) and the lack of knowledge of the benefits that innovation will ultimately deliver, see Stoneman (1987). Barber and White (1987) point out to the difficulties for private investors to internalize the long term dynamic benefits of innovation (and clean innovation is long term and dynamic). Relative support needs decrease with proximity of the innovation activities to the market (since risks decrease as well). However, overall investments needed increase. Then, in the case of clean innovation, the total amount of public funds needed in development and demonstration may actually increase with respect to early research stages, see Grubb (2003).

Climate policies currently implemented are unlikely to avoid environmental disaster, see IEA (2010). Taking the lead, the European Union (EU) has committed to reduce its $\mathrm{CO} 2$ emissions by $80 \%$ by 2050 compared to 1990 levels. Meeting this objective requires using at large scale a large number of low-C technologies, much of which are not yet competitive (nor even technically proven). Clean RD\&D activities within the EU and elsewhere will need to increase significantly in order to develop new clean technologies and bring existing ones to competitiveness.

Current carbon prices are not high enough. What is more, prices in the future are not deemed to follow a stable and adequate path, see Aghion et al. (2009). Adequate carbon prices should provide strong enough incentives for private parties to make use of clean energy technologies. However, other existing market failures, if not addressed, would tilt the balance in favor of already existing, close to the market, clean technologies. A major market failure is that RD\&D has, or should have, a large element of public good, as it is both unlikely, and may be undesirable, that innovators capture all the learning benefits. What is more, there are additional indirect benefits to the $\mathrm{EU}$ as a whole and its member countries in encouraging other countries to adopt better low-C solutions to reduce global warming, which impacts the EU. These benefits are again not captured by the innovator. Additionally, future market revenues from the exploitation of new clean technologies will be moderate due to the fact that products or services resulting from the use of these technologies 
(electric energy in the case of low-C generation) will be essentially the same as those resulting from the use of their carbon intensive counterparts (fossil fuel based generation for generation technologies). Therefore, setting aside the carbon price, there will be pure price competition between new low- $C$ technologies and already established high-C ones. Finally, due to the low level of maturity of most clean technologies, market revenues from their exploitation are subject to high uncertainty. All this taken together results in existing demand pull measures within the EU, namely carbon pricing and the Renewables Directive, being insufficient to deliver an adequate and timely level of private RD\&D. These arguments are further developed in Newbery et al. (2011). Further public support to be implemented should pull the demand for close-to-the-market technologies (market pull instruments) and finance RD\&D to decrease the cost and improve the performance of highly immature ones (technology push instruments).

Regulation induced innovation incentives, like the implementation of standards, or long term commitments to a technology or policy objective, may be cheaper from a public perspective than financial support. However, if standards are set to support immature technologies, they may enforce the adoption of a technology option that ends up not being the most valuable one (though at the time of setting the standard it seemed to be). The mandatory enforcement of long term climate policy objectives alone does not support those clean technologies that currently are not able to compete with more mature ones (those technologies in the pre-deployment stage, which are the focus of our research). Enforcing long term objectives alone would tilt the balance in favor of more mature technologies. This could be very damaging in the long term, where we will also need clean technologies that are now immature but have a high potential. Regulation incentives have a low public cost but, if not applied in combination with other instruments targeted at immature clean options, will not result in the development of a balanced mix of technologies able to achieve long term climate policy objectives at an acceptable social cost. In other words, regulatory support targeting the use of specific clean energy technologies should be reserved for accelerating the diffusion of mature ones ready to be used at large scale, see Popp et al. (2009). Therefore, regulatory support, like other demand pull measures discussed above, cannot replace public funding support of the development of immature technologies. This article provides guidelines on how to frame this funding support.

In any case, public funding support for innovation should complement rather than replace private investments. Public authorities have proved not to be best suited to identify winning technologies, while publicly conducted innovation has generally turned out to be highly cost inefficient.1 On the other hand, RD\&D activities where the private sector has been actively involved have shown, on average, a remarkably higher rate of success. 2

There is ample evidence of success and failure in the use of public funds to support innovation, mainly in the United States. The authors in Alic et al. (2007) identify those features of climate and technology innovation policies that have led to success and failure within the US. Those in National Research Council (2001) provide an overview of research funded by the US Department of Energy and determine driving factors of innovation success. Cohen and Noll (1991) provide evidence of the inefficient use of public general innovation funds in the US. Experience documented within Europe is scarce. Most published works, like the European Investment Bank's EIB (2010), or the Energy technologies Institute's ETI (2010), provide instances of the application of specific funding instruments but do not discuss results obtained. 
Publications collecting experience with the use of different support instruments are complemented by other works conceptually analyzing the use of specific instruments. Some of these works do not address any specific innovation field. Thus, Carpenter and Petersen (2002) and Lerner (2002) argue that public equity investments may be very useful to support any type of innovation conducted in small entities, while Newell (2007) provides evidence of the ability of tax credits to trigger additional innovation of any kind by private investors (both clean and that related to other technologies). Useful insights relevant for any type of innovation can also be found in works relating the use of loans and equity investments in capital markets to the size of the innovating entity (e.g., [Williamson, 1991], [Vicente-Lorente, 2001] and [Wang and Thornhill, 2010]).

On the other hand, there are also published works specifically targeting support to clean innovation. Thus, Newell (2007) also points out that technology prizes may be a suitable instrument in certain types of clean innovation activities. Newell and Wilson (2005) discuss in depth the use of prizes to support early research in the climate change mitigation area.

Complementing previous research, our work provides a first comprehensive analysis of the use of several main types of policy instruments to fund clean energy innovation. In Section 2, we develop criteria for the assessment of the types of innovation to be addressed with each funding instrument; provide specific recommendations on the use of this instrument in clean innovation processes; and compare the different instruments. In any case, given that main features of any clean predeployment innovation project are subject to high uncertainty, we argue throughout the paper that authorities must be willing to reconsider the use of any specific instrument as events unfold allowing them to better understand conditions applying to projects. Afterward, Section 3 is devoted to illustrating the application of guidelines derived in Section 2 to a specific case study: that of publicly supporting the development of new Photovoltaic (PV) generation materials. Criteria here developed are applied to determine which funding instrument is best suited to support the aforementioned innovation process. Conclusions and policy recommendations are provided in Section 4.

\section{Criteria for the assessment of the application of public financing instruments}

This section provides a set of criteria allowing public authorities to compare public funding instruments, and thus helping them to choose which instruments should be used to push the development of clean technologies. Uncertainty on revenues and expenses resulting from an innovation process tends to be very significant. Therefore, estimates of revenues and expenses of clean RD\&D activities, which, as explained later, are one main factor guiding the selection of support instruments to apply, should be refined as innovation work makes progress. Besides, the regulatory and institutional setting in place in each system, or context where innovation takes place, may render the implementation of some instruments difficult and favor others instead. Thus, for example, the general regulatory and fiscal setting in the US seems to be much more favorable to the application of innovation tax incentives than that in Europe.

As explained below, instruments to apply should be tailored to the relevant features of the concerned innovation process including its cost and the level of maturity of the new technology being developed. Costs considered here include all those relevant to the specific project being funded (from the conception of the project to its completion: personnel, materials, facilities, etc.) but not the ones to be incurred subsequently to bring the concerned technology to the market. 
Clean innovation projects whose cost is below ten million euro are deemed to be 'low cost' in the following discussion. The remaining shall be considered 'high cost' projects. Following the classification in EC (2009b), technologies being developed have been divided into (i) those more mature, whose massive deployment within the period (2010-2020) seems feasible, like new wind generation technologies; (ii) those that, if successful, could be deployed within the period (20202035), like Concentrated Solar Power (CSP); and (iii) those whose deployment is unlikely to occur before the year 2035, like nuclear fusion.

When selecting an appropriate funding instrument, we have assumed that relevant conditions in place regulating Intellectual Property (IP) will make the wide and rapid enough adoption of clean technologies and knowledge diffusion compatible with the active involvement of private companies in most clean RD\&D activities, even when partially publicly funded. The authors in Popp et al. (2009) highlight the need to ensure both the diffusion of clean technologies internationally and the protection of private revenues from innovation (need to address knowledge spillovers) while addressing environmental externalities. According to them, combining instruments targeting each of these objectives may not be effective. Then, applying policy instruments specifically designed for clean technologies would become necessary. The tension between these objectives is also analyzed in Barton (2007), Levin et al. (1987), and Henry and Stiglitz (2010). The Energy Technologies Institute (ETI) has implemented a sensible scheme for the management of IP, see ETI (2010).

We propose a set of criteria to characterize both clean innovation projects and the public funding instruments that could potentially support this innovation. Criteria proposed here are not only applicable to clean innovation. These criteria are aimed at providing guidelines for the characterization of the public funding needs of any innovation process. As we show in the remainder of Section 2, clean innovation projects have specific characteristics regarding these criteria. In other words, the features of clean innovation activities (RD\&D) regarding the assessment criteria here identified tend to differ (though this is not always the case) from the characteristics of other main types of innovation. Then, recommendations on the use of financing instruments for clean innovation will differ from those that could be derived for other types of innovation.

The same assessment criteria are used to define the public funding needs of innovation projects and the features of funding support mobilized through each type of financing instrument. Public financing instruments to apply should be selected so that the kind of support they are able to provide best matches the support needs of the concerned innovation process (see Fig. 1). As already explained, the knowledge we have about the funding needs of an innovation process may easily change as time passes and the prospects of the corresponding technology are better known. 
Fig. 1.: Analytical framework to be applied to select financing instruments to apply

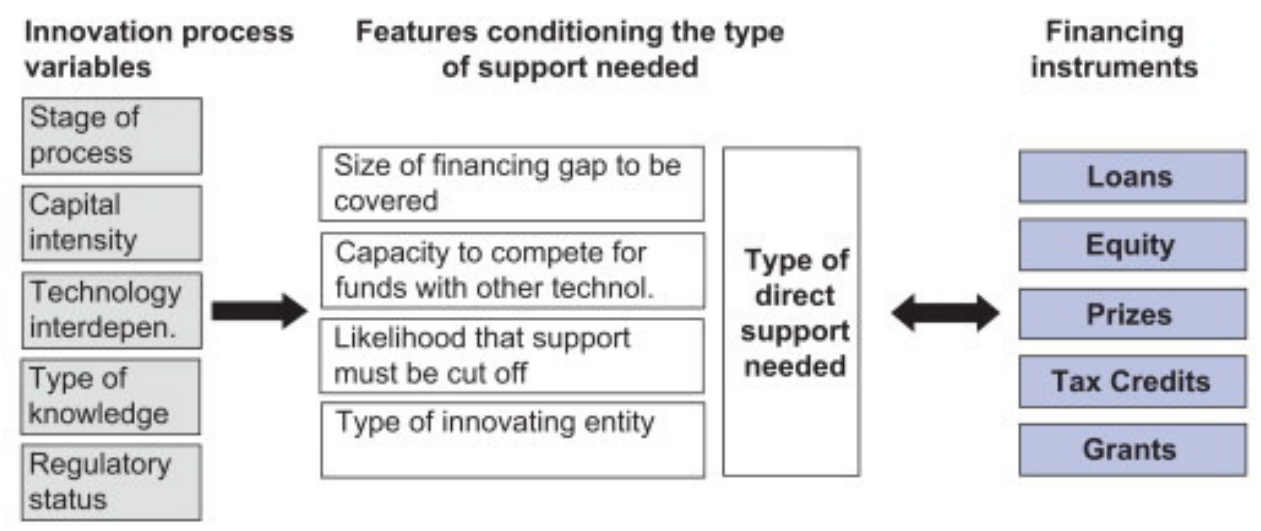

Aim at maximizing social welfare by using those instruments:

1) able to trigger targeted innovation (which may need to change when uncertainty about clean technologies potential decreases)

2) while mobilizing the lowest amount of public funds possible

First, in Section 2.1, we argue which main features, or classification criteria, of an innovation process should be taken into account to determine the type of public funding support it needs. We also try to identify the prevailing characteristics of clean pre-deployment innovation (that of concern here) according to these criteria. Afterward, in Section 2.2 we characterize the type of support provided through each instrument and, based on this and the features of clean innovation processes, we provide some indications on which type of clean innovation processes can be supported with this instrument.

\subsection{Criteria driving the selection of instruments to apply}

As explained in Section 1, existing spillovers of clean innovation and other market failures affecting these activities result in private funds in clean innovation falling short of funding needs. According to the European Commission EC (2009b), investments in clean innovation within the EU should treble in the next decade from $€ 3.5$ bn spent in the year 2007 to about $€ 10$ bn to be spent annually in the decade 2010-2020. Due to the existing market failures, private investments are unlikely to increase in the same proportion. Thus, the relative contribution of public investments will have to increase substantially. Policy instruments employed should mobilize a large enough amount of net public funds 3 to make innovation activities targeted attractive to potential innovators and private investors.

However, public innovation funds should not replace private investments but complement them. Public funds are scarce, especially in the current economic crisis context, where significant public budget adjustments need to take place in many EU countries. Thus, as explained latter in this section, the larger the ratio of private to public funds in each project, the larger the number of innovation projects that will be supported. What is more, according to empirical evidence provided by National Research Council (2001) and Cohen and Noll (1991), publicly conducted RD\&D (or that 
$100 \%$ publicly financed) typically has a lower rate of success and is less cost efficient than privately conducted one.

In order to be effective, public funds must reach the innovation process targeted and the entity deemed to carry it out. Therefore, when the commercial appeal of innovation concerned is lower than that of other innovation, public funds should be specifically granted to the former. This is the case of a vast majority of innovation projects to develop highly immature, capital-intensive technologies. If RD\&D supported has a low probability of success, public support should be flexible enough for authorities to be able to easily redirect it to other, more promising activities, if necessary. This should reduce the risk of funding failure, which, as showed by authors in Cohen and Noll (1991) and National Research Council (2001), has traditionally plagued a large fraction of innovation activities supported publicly.

Finally, the format of public funds should adapt to the characteristics of the innovating entity deemed to carry out the considered RD\&D activities so that this entity can benefit from the support provided. This is discussed by Lerner (2002) for equity investments and loans devoted to support general innovation. Afterward, Newell (2007) and Newell and Wilson (2005) discuss the use of tax credits used to fund general innovation and technology prizes used to fund clean energy innovation, respectively. Authors in Wang and Thornhill (2010) discuss how well equity and loan markets adapt to the characteristics of firms in general and their investments.

According to the previous discussion, the features of an innovation process that directly condition the type of financial support it requires include:

i. the net amount of public funds to be provided to make it attractive (size of the funding gap);

ii. the capacity of the concerned technology to compete for public funds in the market with other clean technologies;

iii. the likelihood that support to this technology needs to be cut off because this technology fails to deliver according to authorities' initial expectations; and

iv. the type of innovating entity that is best suited to carry out this innovation process.

The next paragraphs discuss briefly how to characterize an innovation process in general, and clean innovation ones in particular, according to these features.

\subsubsection{Size of the financing gap}

The funding gap depends on the likely costs of the innovation process relative to its expected future revenues. Both costs and revenues of a project are uncertain. Thus, first estimates of revenues and expenses should be revisited as innovation activities are undertaken and more is learnt about them. Revenues and expenses of innovation depend on the probability that the technology targeted reaches the market and the respective timing of market revenues, which are highly uncertain. The cost of a process and the revenues resulting from it ultimately depend on a number of factors which are next listed:

- the maturity of the technology addressed. The cost of a project tends to increase the closer the technology is to deployment, as explained in Grubb (2003); 
- the cost-intensity of this technology;

- its dependence on other innovations or infrastructure to be built. See, for example, the results from the work on the deployment of Carbon Capture Transportation and Storage (CCTS) described in Middleton and Bielicki (2009);

- the type of knowledge to be acquired through this innovation, i.e., radical versus incremental. Foxon (2003) shows that these two types of innovation face different barriers and Czarnitzki and Hottenrott (2011) provides empirical evidence of the funding gap of radical innovation; and

- the regulatory status of the innovating entity. Benefits of regulated entities are regulated, and therefore limited, as explained for the case of regulated activities in the electricity sector in Pérez-Arriaga et al. (2011).

Given the relevance of market failures weakening private incentives to invest in pre-deployment clean RD\&D, the financing gap of most of these processes is deemed to be significantly higher, on average terms, than that existing in other types of innovation activities, where expected market revenues from the exploitation of the resulting technologies are significantly higher, as explained in Newbery et al., (2011).

\subsubsection{Capacity of this technology to compete with others for public funds}

This depends on the level of maturity of the technology. Popp (2010) shows that private parties have a tendency to invest in close-to-the-market clean technologies, which are able to produce market revenues already in the short- to medium-term. Thus, if a technology is less mature than alternative technologies that also require direct public support, public authorities will have to earmark the necessary support funds. Those clean technologies that are mature enough should be left to compete for public funds, since this should drive down costs and favor innovation. By using prizes when appropriate, competition can still be used within immature technology classes to deliver similar benefits.

Support to a significant fraction of required clean technologies will have to be earmarked. This is especially true for those that will only play a relevant role in the long-term future (2030-2050). Despite being highly immature, many of these clean technologies could be central to achieving longterm climate policy objectives and therefore avoid catastrophic climate damage. Therefore, at their current stage of development, dedicated support should protect these technologies from competition with existing more mature fossil-fuel-based technologies and other clean ones.

\subsubsection{Likelihood that the support for this technology needs to be cut off}

High ex-ante potential gains may justify the undertaking of projects whose probability of success is considered to be low. If information collected during the project reveals that prospects are not as favorable as initially expected, support to the corresponding technologies may need to be interrupted. Both private and social returns resulting from clean pre-deployment innovation tend to be highly uncertain. Private investors, like venture capital and seed innovation ones, tend to be more specialized and have a deeper knowledge of the technologies they focus on, which allows them to 
better estimate the potential of the latter. There are nevertheless some clean technologies, like nuclear, whose features (very large investments needed, high regulatory uncertainty) make them unattractive to private investors if not backed by public entities. Public authorities have developed a high expertise in assessing the prospects of the latter technologies (especially in some leading countries like France). The probability of failure of a project should condition the way the original support is provided to reduce the risk of funding failure. Support to many highly immature clean technologies that could potentially be very relevant to cut emissions in the long term future may probably have to be cut-off.

\subsubsection{Type of innovating entity carrying out this process}

Public support will only trigger innovation activities if it reaches the entities likely and able to undertake the desired RD\&D. Whether or not an entity is suitable will depend on (i) the cost of innovation processes; (ii) whether this innovation is radical or incremental (and matched to the entities' past record of such incremental improvements); (iii) whether the concerned innovation requires integration with a small or large number of related innovations and/or processes; and (iv) whether the technology, or process, to be developed, will be used in a regulated or deregulated activity. Costly RD\&D can only be afforded by large companies, who are also best placed to deliver incremental improvements rather than radical innovation, which typically is best carried out by small innovating entities.4 An innovation involving several technologies is better carried out by entities with cross-technology expertise or through collaborative research partnerships. The European Commission, in its Impact Assessment accompanying the Strategic Energy Technology (SET)-Plan, analyzes several possible institutional settings of clean innovation activity in Europe. They conclude that big, multi-technology, umbrella innovating institutions may be superior to other types of organizations when addressing some specific types of technologies, though, overall, they are not recommended as the option to implement, see EC (2009b). Finally, entities that provide a regulated energy service (transmission and distribution ones in the energy sector) are generally only suited to developing technical solutions (processes) to be applied in their activities. Regulated entities cannot be active in deregulated activities within their sectors because of the large market power that their position in regulated segments provides them with, see Pérez-Arriaga et al. (2008).

The type of entities best suited to conduct clean pre-deployment RD\&D may vary substantially with the specific innovation process addressed. Clean innovation comprises both extra-high capital intensive innovation activities, like nuclear fusion, that can only be undertaken by large international consortiums, and low capital intensive innovation activities like those addressing the development of new photosensitive materials to be used in PV plants. Clean innovation may be radical or incremental. It may concern the use of just one or several technologies together, like CCTS. Finally, though most clean energy innovation will be developed by entities that are active in deregulated activities, there is some clean RD\&D, like process innovation to be applied in network activities, which are best conducted by regulated entities like Transmission and Distribution companies. Therefore, no general conclusion can be drawn on the type of innovating entity most relevant to clean RD\&D.

Finally, the greater the ratio of private to public innovation funds, the larger the number of projects that can be publicly supported, and, other things equal, the higher the expected overall social welfare increase that takes place. 5 Therefore, direct support provided to an innovation process 
should have the lowest public cost possible that is compatible with the project being undertaken and the results being effectively disseminated. The choice of support instrument should then be made according to (a) the ability of each instrument to trigger the concerned innovation process at reasonable public cost; (b) its ability to target the considered technology and redirect support to others if necessary; and (c) whether this instrument is able to reach the type of innovator that is best suited to conduct the targeted innovation activities. Fig. 1 illustrates the application of the analytical framework that has just been laid out.

\subsection{Assessing the application of available instruments}

We assess the use of three different types of policy instruments directly mobilizing public funds to support innovation:

i. public loans, or guarantees provided by public bodies backing private loans;

ii. public investments in the equity of innovating companies whereby the public sector becomes a shareholder of the latter, being able to participate in the management of these companies and gaining access to part of their benefits; and

iii. subsidies or grants involving the provision of public funds that need not be paid back.

We have focused on these instruments because they are the ones most frequently used in innovation programs and discussed in the technical literature. Most public payments supporting clean innovation projects adopt the form of one of these instruments. Several public financing instruments may be used together. Thus, for example, public loans where interest rates are set below well informed market levels can be deemed a combination of a loan and a subsidy. However, we believe that, in most cases, the effects of using a combination of instruments can be estimated as the result of superimposing the isolated effects of each of the combined instruments. Subsidies can be classified into three different types: (i) prizes awarded in contests to carry out a certain innovation activity; (ii) tax credits or other benefits that are proportional to the level of private expenditures on RD\&D already incurred; and (iii) grants or contracts awarded to an entity or consortium.

As already argued, the set of criteria defined within Section 2.1 should be used to characterize both the type of support required by innovation projects and the type of support provided by funding instruments. Therefore, these criteria are now applied to determine which types of projects are best financed with each type of instrument. Experience with the application of each instrument is also taken into account.

For each instrument and assessment criterion, we first determine the features of this instrument according to this criterion and, then, based on these, the type of innovation processes in general, and clean innovation processes in particular, where this instrument could be applied taking only into account this criterion. Once the application of each instrument has been assessed according to all criteria, we provide some representative instances of clean energy innovation processes where this instrument could be used, and the limitations of the use of this instrument. 


\subsubsection{Public loans or loan guarantees}

\section{Experience with the use of this instrument}

Loans have mainly funded expensive innovation activities in the later stages of development and demonstration. We have not been able to find evidence of the successful application of public loans to fund pre-deployment clean energy RD\&D. The Risk Sharing Financing Facility (RSFF)6 jointly created by the European Investment Bank and the European Commission is a good example of the use of loans to fund RD\&D. RSFF loans have managed to leverage a significant amount of private investments in RD\&D either alone or in combination with other support instruments. Projects financed by the RSFF included the demonstration of CSP plants (also backed with deployment support systems), the development of the bio-ethanol technology or hydrogen fuel cell research, see also EIB (2010). According to the US government plans, loan guarantees shall be used to support the construction of Generation 3 nuclear plants and demonstrate their commercial viability. However, some difficulties are being found to make the corresponding deals, see Reuters (2010). These difficulties include the uncertain economics of nuclear plants of this type; disunity among innovation partners; large compensations to be paid by private partners to the government for the public cost of loans provided; and the inability of the government to commit loan guarantee money approved by the Congress, see Wald (2010).

\section{Ability of this instrument to fund innovation activities}

According to Carpenter and Petersen (2002), Lerner (2002) and Wang and Thornhill (2010), loans provided by private lending entities may be attractive to large innovators conducting commercially appealing research in an amount that is commensurate with their size, provided the results of this research are not protected through industrial secret. Financing through debt an amount of RD\&D activities that is larger than what the innovating entities' size would advise may put at risk the financial viability of the innovating entity, which would cause financial distress in it and reduce the probability of success of the innovation conducted. When the results of innovation are kept secret to protect them (assets produced are opaque), the lender has more difficulties to assess credit risk and interest rates offered by him increase, making loans less attractive to the innovator, see VicenteLorente (2001). In any case, and as discussed above, a major part of clean energy pre-deployment RD\&D is not commercially appealing thus not being suitable to be supported through public loans.

Public loans provided according to profit-oriented criteria7 do not involve the provision of a net amount of public funds to the innovator, since the amount of funds obtained through them must be paid back to the investor together with the agreed, profit-oriented, interests. This seems to suggest that public loans should not trigger any innovation activity in addition to those already financed by private ones. However, public loans reduce the total amount of funds to be obtained from private investors. Besides, if the public sector is knowledgeable in the concerned field, the concession of a public loan to a project may attract additional private investors by signaling the quality of the research conducted. Then, public loans should result in a reduction of the contribution required from each private investor, thus allowing the latter to diversify his portfolio of innovation investments when the funding needs of the concerned innovation projects are large. Portfolio diversification is especially important for early innovation investments given their risky nature.

Therefore, loans should be able to trigger pre-deployment RD\&D which is expected to be profitable, is not protected through secret, and is conducted by entities (or consortiums) that are large enough 
to have a reasonable certainty that they will be able to pay back these loans. This innovation will not be triggered by private loans (which should be generally considered before public loans as a funding option) if, despite being thought to be profitable, this innovation does not appeal to private lenders because it is (i) highly capital intensive or (ii) relates to a field where the public sector is better informed than private investors about the risks involved in innovation activities. In the case 'ii' just mentioned, the public sector should be able to offer interest rates below market ones, which should trigger additional RD\&D. Therefore, public loans may be needed to close the funding gap of this type of innovation processes.

Clean pre-deployment RD\&D is, for its most part, not very attractive, commercially speaking. However, public loans should be able to trigger the development of clean technologies that are deemed to be part of the energy technology mix to be used in the future (and are therefore thought to be going to be profitable) but are very capital intensive, or have traditionally been developed through the use of public funds or by public innovating entities. Given that loans are to be used mainly by large companies, this instrument should support incremental innovation affecting already existing technologies (like incremental improvements of the performance of well known PV or wind technology options). Large companies having been working for a long time on the development of these technologies could take advantage of their experience.

Public loans should also be considered at times when there is not enough liquidity in the capital market, as in financial crises. Finally, public guarantees for private loans, which involve the same allocation of risks as public loans, should be used if the liquidity of the capital market is high.

\section{Public cost of the use of this instrument}

Pure public loans should, on average, have a low cost for the tax payer, since they are provided according to profit-oriented criteria and apply interest rates reflecting inherent risks. Costs related to the selection of projects to fund, the management and monitoring of these loans and eventual defaults can be internalized in negotiated interest rates. Assuming enough liquidity exists, public loans (or publicly backed private loans) could be provided to a large number of innovation processes needing them as long as there is reasonable certainty that innovating entities will be able to pay these loans back. Regarding clean pre-deployment innovation, there should be enough public funds to support through public loans a large number of projects conducted by large entities like incremental research, development, and demonstration work focused on new wind turbines, main prevailing solar technologies or new nuclear ones.

\section{Targeting of technologies by this instrument}

Public loans or loan guarantees are normally provided to a specific innovation process. Therefore, they target a specific technology or technical option. The choice of which innovator or projectcompany receives a loan is with authorities, while loan provisions can specify the use to be made of funds provided. Loans can lead to a financing lock-in when, in order not to write off the funds provided to an innovating entity that is not able to pay credits back, public authorities keep providing further support to avoid its bankruptcy. Thus, public loans should not fund innovation activities conducted by entities that are small compared to the size of the projects they plan to undertake.

Public loans could be used in clean innovation processes that need to be specifically targeted by public authorities because, being less commercially appealing than other clean projects, they cannot 
compete with the latter for public funds allocated by private parties. Besides, the size of public loans addressed at pre-deployment (and therefore generally risky) innovation processes should not be big compared to the size of the innovating entity receiving the loan. Therefore, the majority of clean pre-deployment RD\&D conducted by large entities could be targeted by public loans (see the examples provided when assessing the public cost of projects to be supported with this instrument).

\section{Type of innovating entity to receive this kind of support}

As already pointed out and discussed in Carpenter and Petersen (2002) and Wang and Thornhill (2010), public loans are best suited to fund pre-deployment RD\&D conducted by large innovating entities whose financial capability to pay back these loans, and others previously obtained, is proven. These entities could obtain private loans or public ones. Thus, public loans supporting very highly capital intensive innovation projects should only be provided to very large firms or consortiums of medium to large ones. Being less intrusive than equity investments, as explained by Williamson (1991), entities with a large enough size will generally find loans more attractive than external equity. Based on this, one can conclude that loans targeting clean innovation processes should be attractive to large entities like those referred to in the previous paragraphs.

\section{Some instances of clean innovation activities to be funded with this instrument}

According to the previous discussion, clean pre-deployment RD\&D to be funded using public loans includes, among other projects, nuclear fission RD\&D activities targeting new generation technologies. These are capital intensive activities conducted by large innovating entities (very large manufacturers). Besides, the public sector in some leading countries, like France, have traditionally adopted a central role in these activities, and is therefore very knowledgeable.

Public loans could also trigger innovation activities related to the demonstration of the CCTS value chain once the significant techno-economic uncertainties currently menacing the deployment of this technology have cleared. In other words, if CCTS (or any other capital intensive, CO2 reduction, technical option requiring cross-technology expertise) manages to overcome major technoeconomic risks, then public loans could fund those innovation processes required to complete its development. If the decision is made to pursue the demonstration and deployment of CCTS, public loans alone would not be able to trigger main innovation activities at the current stage of development of this technology. Therefore, if applied now to fund the development of CCTS, public loans should be combined with other support instruments mobilizing a larger amount of public funds.

\section{Limitations of the use of this instrument}

Public loans are not able to close the funding gap of most clean innovation activities. Only specific, close to be mature technologies requiring incremental innovation should be supported with public loans. Loans should only be granted to large entities to avoid a financing lock-in if the company is not successful in RD\&D activities (many small companies would not be able to pay back a loan in this case). Loans are not well suited to inducing competition among innovators.

\subsubsection{Public-private equity partnerships (PPEPs)}

\section{Experience with the use of this instrument}


Most equity investments in innovation processes have traditionally addressed technologies that were already available for their wide-scale deployment, though seed equity investments have also been employed at the pre-deployment stage. The preponderance of equity investments in relatively mature technologies is explained by two facts: (i) investments required for deployment tend to be much larger than those required for the development of technologies; (ii) returns to the predeployment stage are normally subject to significant uncertainty, which private investors may not know how to manage. Here, as Lerner (2002) argues, public equity investments, subsidies, and public loans may play an important role by certifying firms to outside investors, who might then be more willing to make further investments. Lerner also points to experience that shows that the extent of private venture capital equity may be largely conditioned by financial regulation, which may restrict such investments to certain funds (excluding, e.g., pension funds). The tax treatment of private venture capital also has an impact, i.e., whether and what strength of fiscal incentives exist for this type of investment. Financial and tax regulation clearly are location dependent.

As to clean pre-deployment investments, the evidence available suggests that PPEPs have been predominantly used to fund inexpensive innovation activities in the early stages of research and development. The Carbon Trust Investments Ltd. (CTIL) has invested in various technologies in the UK (Concentrated Solar Power (CSP), wave, bio-fuels and energy efficiency) but never more than a few million pounds in a single firm. The CTIL requires co-financing by private parties, which has amounted to several times the amount provided by the Trust. The Trust closely monitors the activity of companies supported and participates in their management. Currently, the Trust investments show a rate-of-return of about 19\%, see MHB (2007).

\section{Ability of this instrument to fund innovation activities}

According to Carpenter and Petersen (2002), Lerner (2002) and Wang and Thornhill (2010), private equity investments can trigger pre-deployment, commercially attractive RD\&D (where revenues resulting from activities, even if uncertain, can be reasonably expected to surpass expenses) carried out mainly by entities that are small compared to their project portfolio. Unlike debt, external equity does not create financial distress when innovation investments financed through it are large compared to the size of the innovating firm. This is due to the fact that payments to equity owners are contingent on the success of RD\&D. Besides, external equity provides small entities with the collateral they need to obtain additional debt-based funds. Finally, equity owners can help to drive innovation activity, which can increase its probability of success and, therefore, also help to close the existing financing gap. However, some firm managers may want to avoid the influence of new equity providers.

External equity has far fewer advantages over loans when the cost of RD\&D to be financed is small compared to the size of the firm undertaking it. Carpenter and Petersen (2002) also point out that equity issues have a large cost for those being already equity owners (the value of their shares diminishes). This leads large enough firms to avoid, if possible, obtaining funds in the form of equity. Instead, large firms tend to use loans. Besides, large innovating entities normally have access to substantial internal expertise on the management of innovation activities as well as far more favorable interest rates in the lending market. All-in-all, these firms can probably finance clean innovation projects without resorting to external equity, which is the most intrusive and complicated form of governance, and therefore involves significant costs as explained by Williamson (1991). 
Public equity financing reduces private costs and expected revenues of innovation projects in the same proportion. Therefore, it does not alter (increase) expected net profits from private equity investments. However, similar to publicly owned debt, publicly owned equity reduces the size of the required contributions of funds from private investors, thus allowing them to diversify their portfolio of risky assets. It also allows authorities to certify firms to outside investors, see Lerner (2002).

Then, publicly owned equity can trigger pre-deployment, innovation activities normally conducted by small entities when, despite being expected to render positive net market revenues, these activities are not appealing to private equity investors considered alone because:

- they are too expensive for private investors; or

- they relate to a field where the public sector is better informed than private investors about the risks involved in innovation projects; or

- they are to be financed at times when there is not enough liquidity in the private equity market.

Clean innovation processes whose financing gap can be closed by public equity investments include: (i) early innovation processes with a high commercial potential, like inexpensive radical innovations by university spin-offs focused on the creation of new materials to be used in Renewable Energy Sources (RES) Generation, or the synthesis in small laboratories of bacteria or algae processing $\mathrm{CO} 2$; and (ii) closer-to-the-market RD\&D with good commercial prospects, like the demonstration of the functioning of new cost competitive clean power production options. Public support may be necessary if required investments are relatively high or innovation activity takes place in a sector where local public agencies or bodies have traditionally played a relevant role. The funding gap to close with public equity investments may be lower than that to close with public loans if RD\&D activities are to be carried out by small entities and have a medium-to-high cost.

\section{Public cost of the use of this instrument}

Williamson (1991) suggests that equity investments eliminate opacity barriers to the entry of public investors, by allowing them to access information on the financial situation of the firm and participate in the managerial decisions, and allow them to profit from innovation projects' success or the residual value of the firm. Besides, as Lerner (2002) points out, these investments do not create financial distress. Wang and Thornhill (2010) point out that the risk of losses can be reduced through portfolio selection. This requires that each individual investment, public or private, is of a limited size, which can be facilitated through public equity investments. Therefore, public equity investments should be less costly for public investors than grants or public loans if (i) the size of investments is not large; and (ii) these equity investments target projects with a high commercial potential. When innovation results are protected through secret, the financing gap to be funded with equity investments is smaller than that to be funded with other instruments. Equity investments are less costly for public investors, the better they can assess the potential and risks of targeted projects, or, equivalently, the more experienced the public sector is in the development and exploitation of this technology.

Then, publicly funding through equity investments in the very early stages of development of capitalintensive clean technologies with a high commercial potential, or any pre-deployment stage of development of low-capital intensive, albeit commercially promising, technologies, is not expensive for the public sector, especially if it has been previously involved in the development of similar 
technologies. This may be the case of a significant part of innovation projects addressing highly immature technologies that are part of the future energy mix in most studies, like PV and CSP. Innovation activity targeting these technologies should, for a large part, focus on research. The same could happen for energy efficient innovation projects, which in most cases have a low cost.

\section{Targeting of technologies by this instrument}

PPEPs allow authorities to choose which innovation processes to back, but it may be harder to introduce competition for these funds - although the act of choosing which company to invest in represents a form of competition. Thus, public equity should only be used to support technologies that cannot yet compete with other clean options for funds in the market. If the equity market is liquid enough, setting criteria to determine project failure allows projects to be terminated before they become too expensive. Then, equity providers can work to direct the focus of the activity of the innovating entity to another project or sell their participation in the ownership of this entity. Thus, financing lock-in resulting from the use of other support instruments like loans can be avoided if public equity investments are used instead, since, in this case, quitting or redirecting support by investors is easier. Public equity is thus more flexible than loans when financing small innovating entities.

According to this, clean innovation projects targeted by publicly owned equity could include RD\&D which is not commercially attractive because other clean technologies are more mature or the private sector is more experienced in the latter. The fact that equity investments represent a large fraction of the capital of the innovating entity should not lead to a financing lock-in. Then, public equity can target projects conducted both by small and big companies focused on immature technologies like wave and tidal power, or new CSP prototypes, among many.

\section{Type of innovating entity to receive this kind of support}

Public authorities investing in the equity of an innovating firm would like the value of their investment to be associated to that of the targeted innovation. However, only the market value of small entities or project companies is intimately associated with the success of each innovation project they undertake. Then, only equity investments in these entities allow the public sector to appropriately profit from the success of the innovation projects it funds. Besides, as already discussed, external equity is better suited than loans to triggering innovation activities in small entities.

According to this, public equity investments may fund the development of radically new technologies, since small companies are less biased against the use of these technologies. Clean innovation targeted should address the early stages of development of these technologies (which tend to be less expensive) or any stage if technologies have a low capital intensity. A specific process to support with these investments could be research focused on the development of new materials that could significantly improve the efficiency of well spread technologies, like wind, but especially PV or CSP (where the potential for improvement is larger). Another example is innovation contributing to a radical improvement of the performance of very widely used energy consuming equipment (like light bulbs).

\section{Some instances of clean innovation activities to be funded with this instrument}

Public innovation processes that should be financed through publicly owned equity include early research which is not very expensive but is not very cheap either, with a high commercial potential, 
and, preferably, targeted at radically new technologies. An example of this is research relevant to the development of new materials to be used in radically new technological options (with a much improved performance) for well-spread technologies like PV, or fuel cells. Equity investments may also be relevant to early innovation radically changing the energy performance of not very costly devices.

\section{Limitations of the use of this instrument}

Public equity investments are generally not appropriate to support very expensive innovation activities, or those conducted by large entities undertaking many other activities (large energy technology manufacturers or utilities). Equity investments can only fund clean innovation projects that are deemed to be profitable. This instrument does not allow innovators to choose which innovation project to be supported with public funds (normally the decision is with investors).

\subsubsection{Prizes awarded to the winner of a contest}

\section{Experience with the use of this instrument}

Prizes have typically been awarded to successful innovators in contests organized to conduct inexpensive, radical, research and development work including the construction of first prototypes. The National Aero Space Agency (NASA) Centennial Challenges Power Beaming Competition focused on technologies that could allow photovoltaic cells in the outer space to beam power to earth. No winner was found, but the prize triggered a significant amount of research that allowed the technology to be pushed forward, see NASA (2010). Also, the Massachusetts Institute of Technology (MIT) Clean Energy Prize has funded revolutionary innovation like an electrode able to increase the amount of light penetrating PV panels, see MIT (2010).

\section{Ability of this instrument to fund innovation activities}

Prizes place techno-economic risks of RD\&D activities on the innovator. Prizes are only awarded to those entities that accomplish the technological achievement being targeted. Thus, prizes awarded must be much larger than those grants that would suffice to trigger the same innovation process. As acknowledged by Newell and Wilson (2005), prizes properly designed offered to undertake costly processes would then have to be very large in size. Besides, Newell and Wilson point out that upfront investments in the latter type of processes could probably not be afforded by small innovators participating in a contest. Hence, prizes can only trigger inexpensive innovation processes. It is commonly accepted that prizes are more attractive to entities like universities or research institutes that put a high value on the prestige they can get through the former.

Prizes can trigger inexpensive clean RD\&D that, as a consequence of this, is in most cases focused on the very early stages of the innovation chain. This is reinforced by the fact that prizes are most attractive to universities and research institutes, which are mainly focused on early innovation projects. This concerns research to improve the properties of materials used in clean technologies.

\section{Public cost of the use of this instrument}

Prizes are a form of output-driven subsidy. They entail the provision of public money that is not recovered by the public sector, at least in a direct way. Therefore, they are more expensive than loans or publicly owned equity. However, by rewarding outputs rather than inputs, prizes provide efficiency incentives to the innovator, thus eliminating the risk of moral hazard behavior and 
increasing the probability of success, which ultimately reduces their public cost. Besides, as highlighted in Newell and Wilson (2005), prizes result in contenders exploring parallel research paths, which is highly advisable in risky innovation activities and could, alternatively, only be achieved by funding several research projects. When designing prizes, public authorities should make an estimate of the probability of success of the innovation activity addressed, its cost as well as the number of contenders, see Newell and Wilson (2005). Reasonable estimates of these features of innovation projects should be obtained subject to existing uncertainty and be updated once more information is obtained as innovation activities make some progress. All in all, prizes will only fund successful innovation projects, but their size will be much larger than that required to fund each of the individual technological options researched in parallel by the contenders.

Accordingly, prizes are not expensive for the public sector compared to other financinginstruments when they are awarded to the winners of contests focused on very early research concerned with inexpensive clean technology achievements. Therefore, normally prizes should address highly immature clean technology innovation processes. This concerns research to improve the properties of materials used in clean technologies, or other types of very early clean research.

\section{Targeting of technologies by this instrument}

Competitors in a contest choose how to meet the target set by authorities, offering diversity of approach for the specified goal. Given that prize givers do not commit resources to any specific process, they do not run the risk of being locked-in into funding. These arguments fit well with the support through prizes of very early clean research.

\section{Type of innovating entity to receive this kind of support}

The administrative burden born by participants in prize contests is smaller than that created by other instruments, which enables the participation of small entities. Small entities may have liquidity problems when facing high upfront costs to be paid by innovators in a contest, see Newell and Wilson (2005). However, this should not be a major barrier for the participation of small entities if innovation activities addressed are inexpensive. At the same time, prizes are most valued by research institutions. Thus, according to this criterion, any type of clean innovating entity may be supported through prizes, though research institutions are best placed.

\section{Some instances of clean innovation activities to be funded with this instrument}

Prizes should finance very early, inexpensive, research preferable conducted by research institutions. This includes the development of new materials or early prototypes with relevant, outstanding, features to be used in highly immature clean technologies like CSP or PV, or even more futuristic ones, like power beaming devices aimed at transporting solar energy collected in the outer space, see NASA (2010).

\section{Limitations of the use of this instrument}

Prizes can only trigger inexpensive innovation activities. They are not adapted to funding a specific project but are aimed at creating competition among parallel paths (or projects).

\subsubsection{Tax credits and other benefits associated with private expenditures on RD\&D}

\section{Experience with the use of this instrument}


Ofgem's Innovation Funding Incentive (IFI) is an example of cost-sharing stimulus to innovation. IFI has triggered a significant amount of innovation by Distribution Network Operators (DNOs). DNOs in the UK are recompensed up to $80 \%$ of their investments in new technologies that contribute to the reliable operation of networks in a low-C system. The innovation activities supported under IFI tends to be relatively inexpensive (less than one million pounds). Incentives from IFI are combined with those created by the Retail Price Index (RPI)-X scheme, which is aimed at increasing the efficiency in the development and operation of networks, see Bauknecht et al. (2007). Newell (2007) finds that tax credits in the US supplement rather than replace private innovation funds. He concludes that tax credit schemes in place have resulted in several billion dollars of extra investments in innovation projects.

\section{Ability of these instruments to fund innovation activities}

Evidence provided in Bauknecht et al. (2007) and Newell (2007) shows that tax credits and rebates for RD\&D may trigger a significant amount of additional innovation activities (above $\$ 15 \mathrm{bn}$ in the US in the last years). Being a subsidy associated with previously undertaken innovation investments, tax credits create strong incentives for private parties to carry out extra RD\&D. Therefore, tax credits or rebates may trigger any kind of clean innovation activity as long as:

- the benefits provided by public authorities are linked to undertaking this specific RD\&D activity (which would force public authorities to specify in full detail the innovation processes receiving tax credits or benefits); and

- the benefits provided are relevant to the innovating entity (this leaves out tax credits when the innovating entity is paying a small amount of taxes).

\section{Public cost of the use of this instrument}

Tax credits and rebates are a form of subsidy. Therefore, their public cost is likely to be higher than that of public loans or public equity. However, as experience in the US suggests, tax credits and rebates are less likely to crowd out private investments than conventional public grants and contracts, since tax credits are granted on the condition of private investments having already taken place. Therefore, tax credits create a larger incentive to undertake private investments in RD\&D than conventional contracts or grants since, contrary to the latter, tax credits increase with the size of private investments. Authors in Cohen and Noll (1991) show that public contracts and grants have replaced a large amount of private investments or targeted technologies with low potential that would therefore never attract private investments. On the other hand, Newell (2007) claims that research spending has increased roughly one-for-one with each dollar of tax credit awarded in the US. Therefore, the public cost of innovation projects supported by tax credits is probably lower than that of innovation projects funded with conventional subsidies. This would advice financing with tax credits or rebates any kind of RD\&D that needs to be subsidized (because it is risky and costly) and can be targeted by the former. As we shall explain in the next paragraphs, this last condition mainly applies to innovation activities undertaken within regulated energy entities (process innovation by electricity or gas network companies).

\section{Targeting of technologies by this instrument}

Both tax credit and rebate schemes normally leave the decision on which RD\&D activities to undertake in the hands of private entrepreneurs and investors. These, as Foxon (2003) and others argue, find close to the market activities more attractive than early, risky ones. Thus, private 
revenues from tax credits or rebates are unlikely to be used to fund a significant amount of early RD\&D (pre-deployment one).

Rebate schemes that regulated utilities are subject to may be an exception to this general trend. Within regulated entities, the techno-economic objectives of innovation investments subject to rebates can be guided by the regulator when determining whether to include these investments in the regulated asset base of the firm. At the same time, rebate schemes do not preclude any research path that regulated utilities want to pursue to achieve pre-set objectives.

Assuming that private entities are more agile than the administration in redefining investment priorities, tax credits should be more flexible than conventional subsidies in being directed to successful innovation activities.

Based on this, one should aim to fund at least part of pre-deployment innovation activities within regulated utilities (those taking care of regulated activities in the electricity, gas, and oil industries) using rebates or tax credits.

\section{Type of innovating entity to receive this kind of support}

Tax exemptions can only reach large companies paying a significant amount of taxes. Rebates can be provided to smaller entities as well. In any case, entities receiving this form of support must be large enough to bear upfront investment costs, since these benefit schemes only reward innovation activities already undertaken. Then, rebates and tax credits may probably only trigger clean predeployment RD\&D carried out by large regulated entities.

Note that the level of revenues obtained by regulated utilities from their activities is necessarily limited (their revenues are regulated). This reduces potential increases in market revenues from the innovation projects undertaken, which renders innovation incentives produced by non-subsidized forms of public support too weak to trigger pre-deployment innovation activities within these entities. Regulated utilities are only well suited to conduct innovation activities that are relevant to their activities. They are not allowed to be active both in regulated and deregulated activities because of the level of market power enjoyed by them due to their position as a regulated monopoly holder. Besides, these entities typically are not large and specialized enough to develop new products (technologies). Consequently, tax rebates should most probably support process innovation relevant to regulated (grid) activities in the energy sector.

\section{Some instances of clean innovation activities to be funded with this instrument}

According to arguments provided, tax credits and rebates should be used to support the implementation of innovative, smart, active and more coordinated, and therefore efficient, network operation and expansion solutions.

\section{Limitations of the use of this instrument}

Tax cuts cannot support immature innovation projects that are not most attractive from a commercial point of view. Thus, they are not well suited to fund clean RD\&D in general, but only specific instances of this (mainly that in regulated entities). Besides, tax cuts are not able to support innovation projects by small companies, since they only reward innovation activities already undertaken, hence not alleviating the financing constraints of these companies. They are not able to target a specific technology to support. 


\subsubsection{Conventional subsidies (grants, contracts)}

\section{Experience with the use of this instrument}

Grants and contracts are frequently used to fund clean energy innovation projects of any type. Competition for funds has increased the probability of success of these projects. Competition among technological paths in early research (financing several paths in parallel) has increased the probability of supporting winning options. Most successful near-market subsidized projects have normally received output-driven support (linked to the achievement of objectives). Co-funding and performance monitoring are also common to most successful projects. Finally, the ability to redefine project objectives if necessary has also played a relevant role in overcoming barriers.

The US PV Commercialization Program in the 1970s and 1980s, see Cohen and Noll (1991), shows many of the desired support features. Creating competition among several technological concepts still to be developed led to the identification of the most promising options. The menu of alternatives was gradually reduced. Authorities managed to create some pressure to achieve good results by dropping projects that made slow progress. Given the level of existing uncertainty about the results of research, an agile approach involving local, regional and national authorities, was followed to shift emphasis on options as more knowledge on their potential was gained.

Consistency among the innovating institution' $s$ objectives, its research strategy and internal policies on issues such as the control of intellectual property has proven to be critical. A lack of consistency has created obstacles to sustainability and success, as e.g. shown in Ferrari (2009) for $R \& D$ activities undertaken in nuclear institutes in Central and Eastern Europe.

\section{Ability of this instrument to fund innovation activities}

Conventional (input-driven) subsidies reduce the fraction of the project costs born by the innovating entity, including upfront costs, while not reducing its revenues from this project. Therefore, as experience with the use of financing policy instruments suggests, public grants and contracts can engage innovating entities even in the least commercially appealing clean innovation activities, like expensive, early-stage, clean energy research or a large part of RD\&D activities carried out by regulated energy utilities, whose revenues are limited by regulation. As explained above and discussed in Pérez-Arriaga et al. (2008), regulated energy entities cannot participate in deregulated activities, where market revenues from innovation are driven by market sales, but only in regulated ones, where main revenues are preset by the regulator by applying a reasonable rate of return on investments.

Given the large financing gap of many clean innovation processes, a significant part of clean RD\&D activities can only be triggered through the provision of public grants or contracts. This is shown by records of instruments applied to fund energy innovation projects in general and clean technologies in particular, National Research Council (2001).

Due to existing spillovers discussed in Foxon (2003), Popp (2010) and many others, if innovators in subsidized projects are restricted in the terms of any resulting IPR (Intellectual Property Rights), the private profitability of these projects may decrease significantly. Then, the size of the subsidy required to trigger innovation is bound to increase. 
Output-driven subsidies (those where public funds provided are associated with the achievement of project objectives) are less attractive to innovators the higher the risks involved in the concerned project are. Therefore, they are unlikely to trigger highly risky, expensive research.

All in all, public grants and contracts can close the financing gap of any kind of clean innovation project, even those targeted at the most immature, capital intensive, technologies, like nuclear fusion, or the riskiest innovation activities carried out by regulated utilities. The format of subsidies conditions the required size of these subsidies and whether they can be applied to early RD\&D or closer to the market one.

\section{Public cost of the use of this instrument}

Subsidies are the most expensive support instrument from a public perspective, since public funds provided through them are not paid back to the public sector, at least directly. Output-driven subsidies are less expensive than input-driven subsidies and avoid moral hazard.

Then, all types of innovation processes that are well suited to being supported through other instruments should not be supported through input driven grants and contracts. Input contracts should, therefore, be considered a last resource option.

Output-driven grants and contracts have a lower cost than other output driven subsidies like prizes, since they do not need to be as large as prizes to trigger a specific clean innovation process. However, unlike prizes, a contract does not allow the exploration of different research paths in parallel. Exploring parallel research paths using output driven grants and contracts would require financing all those paths that end-up meeting pre-set objectives, which would probably be more expensive than setting a unique reward for the single winner of a technology contest. Therefore, output driven contracts are more expensive for the public sector than prizes when funding low cost, very early, innovation activities. However, they have a lower public cost when funding closer to the market innovation projects, where parallel research paths need not be explored, or expensive innovation activities, where a reduced number of research paths need to be selected.

\section{Targeting of technologies by this instrument}

Authorities must choose which innovation process to give a contract to. This allows them to target even the least commercially appealing processes. According to experience already collected with the use of subsidies, conventional subsidies to be provided on a continuous basis may lead to a lock-in when authorities keep supporting an innovation project to avoid admitting that they have wasted those funds already spent. This was, for example, the case of the Breeder reactor program or the US Algae Biofuel research program, see Cohen and Noll (1991) and Cagw (2010). Funding lock-in does not occur when one-time subsidies are provided.

Then, grants and contracts force public authorities to target specific clean technology options. This is appropriate for technologies that are mature enough to allow authorities to select a few research paths on which to concentrate public resources (the ones previously identified as most promising) but are not mature enough to compete for public funds with other clean technologies. Most clean technologies fall within this category. Technologies not appropriately targeted by contracts or grants include those immature clean technologies whose development requires exploring multiple research paths, like advanced energy storage technologies as Compressed Air Energy Storage, CAES. Those technologies that are very close to the market, and are therefore already attractive for private investors, (like onshore wind) should not be supported by contracts either. 


\section{Type of innovating entity to receive this kind of support}

Grants and contracts can be provided to any type of clean innovating entity.

\section{Some instances of clean innovation activities to be funded with this instrument}

Input driven contracts should be used to support early, expensive, clean pre-deployment RD\&D. Nuclear fusion is a paradigmatic example of this. Contracts could also be used to support part of risky clean innovation projects conducted by regulated energy utilities. These include the implementation of transmission or distribution network concepts that have not been tested before, or are subject to significant risks not controlled by regulated entities, and can, therefore, be a failure in economic terms.

What is more, the public good nature of clean innovation, together with the fact that products obtained from it (clean energy or services) are similar to those provided by high-Carbon technologies, result in potential profits for innovators resulting from successful projects being significantly smaller than those obtained in other technology sectors. Then, a large fraction of clean innovation projects not addressing the very early stages of the innovation chain will, despite this, have a large funding gap that can only be closed using public grants or contracts.

Output driven contracts setting technical objectives could fund closer to the market innovation activities subject to high market risks. An example of this is the development of CCTS. CCTS is a combination of already proven technologies but there is high uncertainty about its economic viability.

\section{Limitations of the use of this instrument}

Input driven public contracts or grants are too expensive, from a public point of view, to support projects that can be effectively supported using other means. Output driven contracts are not valid to support early RD\&D subject to significant technical risks. Both types of subsidies cannot create competition among technologies because they must target a specific project (technology option).

\section{Case study: R\&D in the design of new solar PV materials}

This chapter illustrates the application of the assessment criteria just developed. The aforementioned criteria guide the choice of the financing instrument best suited to a specific innovation process: R\&D focused on the design of new solar PV materials. Appropriate market conditions are deemed to be in place guaranteeing the deployment of the concerned technology once it reaches maturity. Thus, the following discussion focuses on technology push instruments.

\subsection{Description of the innovation activity to be undertaken}

Solar PV facilities produce electricity from the solar light penetrating panels. When exposed to sunlight, materials used in panels create a voltage, which in turn results in electricity current. This technology is still far from being cost competitive when compared to traditional fossil-fuel based technologies or other more mature renewable power generation technologies such as onshore wind. Thus, a significant amount of research aimed at reducing investment costs and increasing the efficiency of the electricity production process is still required.

Solar photovoltaic is expected to contribute up to $12 \%$ to European electricity supply by 2020 , see EC (2009a). A total amount of €384 million was invested within this region in PV-related research 
projects in 2007 with public funding accounting for $42 \%$ (of which $7 \%$ came from the EU, e.g., FP6, and 35\% from Member States).8 Mid-term strategic objectives relevant to the development of this technology in the EU include the improvement of the technology' $s$ competitiveness and its integration into the electricity grid. Related actions include a long-term R\&D program to enhance the energy yield and reduce production costs, see (ESII, 2010). This will most probably require the design of new PV materials.

\subsection{Need of public support}

The probability of failure of research targeting the development of new PV materials is high, as that of any type of early research. However, if materials developed are employed in a relevant fraction of new PV panels, market revenues from this innovation would be very large. Thus, expected net private revenues from research to be conducted could be positive or negative. If expected net private revenues were negative, this innovation process would need public funding support. However, even if expected net market revenues from this innovation process were deemed to be positive, innovators in Europe might find difficulties to get access to private funding due to the high risks faced by the project and the low level of maturity of the local private equity market. As a matter of fact, a significant amount of equity investments in clean energy innovating companies with a large commercial potential are being funded by public initiatives, see MHB (2007).

\subsection{Type of public support needed}

This innovation process faces high technological risk, since new materials are to be developed and the functioning of new PV panels using them has neither been tested nor demonstrated yet. Furthermore, there may be barriers to the system integration of new PV panels. The capital-intensity of the research of the development of new materials is low. Panels using the new materials might require the adaptation of other technologies currently being used in PV panels. Knowledge produced in this kind of innovation process typically is radical in nature. Thus, innovating entities probably are small in size and participate in deregulated activities.

As already explained, there may be a need for authorities to contribute a positive net amount of public funds to this type of project. However, it is also possible that the expected net profits of this research are positive. PV generation using new materials is not able to compete with other clean technologies for public funds because the production of new materials and its use in panels is being researched now. Therefore, potential market revenues from this innovation process are far more uncertain and distant in the future than those from the development of other more mature clean generation technologies like wind (on-shore and off-shore) or even, already proven, PV technical options. The process of developing new PV materials is subject to high uncertainties about its outcome. Hence, it has a high probability of failure in the sense of not reaching techno-economic objectives, which would lead to the need to terminate R\&D activities and cut off support. Finally, innovating entities undertaking the research of new PV materials are typically specialized solar PV firms or research institutions, i.e. Small and Medium Enterprises (SMEs) participating in deregulated activities.

\subsection{Recommendations on the use of financing policy instruments}

Public loans are not appropriate for this process because it is high-risk research to be undertaken by small entities (probably, new entrants) that may not be able to pay back debt. Tax credits are equally inappropriate given the low chance of taxable profits in small innovating entities. Public equity 
investments can be a suitable form of public support if the expected net profits of this research are positive. These investments should be able to engage small innovators in early, inexpensive, expected to be profitable, research while attracting private investors. Besides, equity investments can result in significant profits for the public sector to be reinvested in other clean innovation projects if materials developed reach the market.

If expected net private revenues of this innovation are negative and the cost of research targeted is very low, prizes would be a suitable public funding option, especially if this research is to be carried out by universities or research institutes. Conventional input-driven subsidies (grants or contracts) should only be used if this research is expected not to be profitable from a private point of view and its cost is significant (output subsidies are not an option due to the high risk of failure of the project).

\section{Conclusions and policy recommendations}

This article provides guidelines on how to choose among main financing policy instruments to support RD\&D in new clean energy technologies. Meeting climate objectives requires having a significantly increased share of low-C generation technologies in the future energy mix. However, most of the technologies to be used in the future are not yet competitive, nor even technically proven. Substantial additional RD\&D activities are thus required in order to achieve the ambitious targets that have already been set.

For a variety of reasons, part of the funding of these activities needs to come from the public sector, i.e., these activities need to be directly supported. Economies of scale enjoyed by high-C technologies together with a lack of differentiation between products of these and low-C technologies result in an insufficient level of private investment in clean RD\&D. Furthermore, existing measures to pull the demand for clean technologies, namely carbon pricing and deployment support measures, will be insufficient to deliver an adequate and timely level of private RD\&D. Carbon prices are not expected to be high and stable enough to support durable low-C investments in the short-to-medium-term future. But, most importantly, the fact that clean energy RD\&D has a large element of pure public good undermines private incentives to invest in it even if the deployment of the corresponding technologies is to be supported.

The form of direct public support needs to be tailored to the features of each innovation project and the type of entity best placed to undertake it. Financing instruments applied must be able to close the gap between the cost of innovation activities and the amount of funds private parties are willing to contribute. Besides, instruments might need to be able to direct support to specific technologies not able to compete for public funds with others or, instead, promote competition among technologies. They may also need to be flexible in (re-) directing funds to alternative innovation projects when projects originally supported fail to deliver the expected results. Finally, public funds mobilized through these instruments should reach potential innovating entities.

The aim of instruments applied is to maximize the amount of socially valuable clean RD\&D subject to public sector' s funding by leveraging private sector funding as far as possible within each stage of project maturity. According to our analysis, loans are well suited to finance expected-to-beprofitable clean RD\&D with well quantifiable future market prospects when these activities are carried out by large companies. Public loans should replace private ones if the liquidity of the capital market is low; the innovation targeted is related to activities where the public sector is more experienced; or required investments are too large and risky for any single potential private lender. 
This applies to the support of clean technologies to be developed through incremental innovation when these technologies should be necessary to achieve the decarbonization of the economy, but are highly capital intensive, or have traditionally been developed within the public sector or financed by it, like nuclear fission.

Publicly owned equity is suitable to finance pre-deployment innovation projects undertaken by small entities, or a project company, if the net profits of this innovation process are likely to be positive and any of the following conditions are met: (i) the private equity market is not developed or liquid enough; (ii) innovation activities are associated with a field where the public sector is more knowledgeable than the private one; or iii) investments required are very large for any single private equity investor. Clean innovation processes to be financed through publicly owned equity include early research which is not very expensive, but is not very cheap either, with a high commercial potential, and, preferably, of a radically new nature, like the development of new materials to be used in solar technologies. Subsidies in the form of technology prizes shall be normally used to fund early, low-cost, clean innovation projects preferably undertaken by universities and research institutes (e.g., research of the development of new materials in clean technologies, or specific early clean technology achievements). Tax credits and other benefits related to RD\&D investments are best suited to supporting clean pre-deployment innovation activities conducted by regulated energy companies like network (transmission or distribution) gas or electric entities. Input driven grants and contracts - on the one hand the most attractive form of support from the innovators' perspective, but on the other the most expensive instrument - should only be awarded to socially desirable clean energy innovation projects that will not be undertaken otherwise and where all other instruments fail. This is clearly the case of early-stage, capital-intensive processes (nuclear fusion) but also applies to a majority of clean pre-deployment RD\&D, given its special features. In the case of very expensive innovation projects, contracts may only fund a reduced fraction of total costs and aim to leverage private investments. Output driven contracts should fund closer to the market innovation processes where the risk of technological failure is relatively low (CCTS demonstration). Conventional subsidies can also play a major role in the support of clean RD\&D activities carried out by regulated entities.

In any case, given the high level of uncertainty affecting clean energy innovation projects, authorities may need to redesign support to them once more information is learnt about the eventual outcome of each project and other uncertainty factors, like the market and regulatory conditions applying to the use of the corresponding technology.

1

The development of the breeder reactor technology, discussed in Cohen and Noll (1991), is a paradigmatic example of the limitations of publicly managed and conducted innovation. This program was the major focus of US federal RD\&D activity from the early 1960s until the cancellation of its demonstration in 1983. Authorities persistently overestimated demand and underestimated the required cost of the development of the breeder reactor technology. When costs exploded, the industry left the project and the federal government took complete control committing further amounts of public funds presumably driven by political considerations rather than socio-economic ones.

2

However, there are certain types of innovation which are well suited to be publicly managed and/or conducted, as authors in Alic et al. (2003) point out. This is the case of early (basic) research conducted at universities and laboratories, where competition among scholars encourages efficiency in innovation. 
Net public funds are the net of those amount of funds provided initially that the innovator must give back to authorities at the end of activities to be conducted.

4

As explained by Foxon (2003), large and well established entities within a field have a conflict of interest when backing radically new technologies able to replace dominant ones if successful, since these firms are interested in capitalizing on past investments they have carried out when developing and promoting well known technologies. Thus, radical innovation is typically conducted by small firms that are new entrants in the field.

5

The obvious qualification is that social welfare may be increased if public funds are used to buy wider access to the Intellectual Property Rights (IPR) produced, and this might argue for higher co-funding of a smaller number of projects.

6

For more information, see http://www.eib.org/products/loans/special/rsff/index.htm. A successful example is the provision of a $€ 200$ million RSFF loan to the Spanish wind turbine manufacturer Gamesa, co-funding its 2008-2011 research program. Additional funds came from Spain and the private innovator. A sustainable R\&D strategy, including diverse projects in turbine and storage technologies is followed based on cooperations with third research centers. Numerous patents could be filed.

7

Loans provided at lower than profit-oriented interest rates actually involve subsidizing the concerned innovation project. Thus, pure public loans should be granted at interest rates computed according to profit oriented criteria taking into account the risk profile of the project and the features of the innovating entity borrowing funds. Note that, acting as an intermediary, the public sector would be able to borrow risky funds at a lower cost, given the fact that it has a wide cost base (the entire public budget, a significant fraction of GDP) to bear that risk.

\section{8}

Countries where solar PV has been deployed at large scale, such as Germany, France, Italy, and the Netherlands, provide most public funds. Despite the limited deployment of the technology in the UK, this country' s public R\&D investments are relatively high as well, EC (2009b). 


\section{References}

Aghion, P., Veugelers, R., Serre, C., 2009. Cold Start for the green Innovation Machine. Bruegel Policy Contribution (2009/12).

Alic, J.A., D.C. Mowery and E.S. Rubin, 2003. US technology and innovation policies: lessons for climate change, Pew Center for Global Climate Change available at

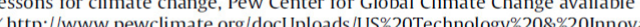
tion\%20Policies\%20\%28pdf\%29.pdf

Arrow, K., 1962. In: Nelson, R. (Ed.), Economic welfare and the allocation of resources for invention, in The Rate and Direction of Inventive Activity, 1971, resources for invention, in The Rate and Direction of Inventive Activit
Princeton University Press, pp 609-625. re-printed in Rosenberg.

Barber, J, White, G., 1987, Current policy practice and problems from a UK perspective. In: Dasgupta and Stoneman's Economic Policy and Technological perspective. In: Dasgupta and Stoneman s
Performance. Cambridge University Press.

Barton, J.H., 2007. Intellectual property and access to clean energy technologies in developing countries. International Centre for Trade and Sustainable Development (ICTSD), Programme on Trade and Environment, pp. 37 (downloaded in October, 2010 from http://ictsd.org/i/events/dialogues/11251/).

Bauknecht, D., Leprich, U., Spath, P., Skytte, K., Esnault, B., 2007. Regulating innovation and innovating regulation. Intelligent Energy Europe project DG-GRID, Directorate General for Energy and Transport. European Commission., pp. 58.

Carpenter, R.E., Petersen, B.C., 2002. Capital market imperfections, high-tech investment, and new equity financing. The Economic Journal 112 (477), 54-72.

Cagw, 2010 Congressional Pig Book Summary. Citizens Against Government Waste. Washington, (downloaded in September, 2010 from <http://www. cagw.org/reports/pigbook/2010/ >).

Cohen, L.R., Noll, R.G., 1991. The Technology Pork Barrel. The Brookings Institution, 400.

Czarnitzki, D., Hottenrott, H., 2011. Financial constraints: routine versus cutting edge R\&D investment. Journal of Economics and Management Strategy 20 (1), $121-15$

EIB, 2010. The Risk Sharing Finance Facility - Frequently Asked Questions. European Investment Bank. (downloaded in July 2010 from 〈http://www. eib.org/attachments/ rsff_faq_31052007.pdf $>$ ).

ESII, 2010. European Solar Industry Initiative: Implementation Plan 2010-2012. European Photovoltaic Industry Association and Photovoltaic Technology Platform

ETI, 2010. How we operate Intellectual Property. Published by the Energy Technologies Institute. (Downloaded in July, 2010 from <http://www.energ technologies.co.uk/Home/Technology-Programmes/How-We-Operate/Intellec tualProperty.aspx $>$ ).

European Commission, 2009a. Accompanying document to the SET-Plan - A Technology Roadmap. SEC 2009, 1295.

European Commission, 2009b. Accompanying document to the SET-Plan - impact assessment. SEC 2009, 1297

Ferrari, M., 2009. Researching success: summary findings of IAEA report on Nuclear Research and Development Institutes in Central and Eastern Europe in June 2009. IAED Bulletin. 51-1.

Foxon, T.J., 2003. Inducing innovation for a low-carbon future: drivers, barriers and policies. The Carbon Trust.

Grubb, M. 2003. Technology innovation and climate change policy: an overview of issues and options. Keio Economic Studies 41 (2), 103-132.

Henry, C., Stiglitz, J.E., 2010. Intellectual property, dissemination of innovation and sustainable development. Global Policy 1 (3), 237-251.
IEA, 2010. World Energy Outlook 2010. IEA/OECD, Paris

Levin, R.C., Klevorick, A.K., Nelson, R.R., Winter, S.G., 1987. Appropriating the returns from industrial research and development. Brookings Papers on Economic Activity 3, 783-820.

Lerner, J., 2002. When bureaucrats meet entrepreneurs: the design of effective 'Public Venture Capital' programmes. The Economic Journal 112 (477) F73-F84.

MHB, 2007. The carbon trust innovation and investment. Report for the National Audit Office. Morgan Harris Burrows LIP, pp. 89 (downloaded in June 2010 . ing.aspx $>$ ).

Middleton, R., Bielicki, J.M., 2009. A scalable infrastructure model for carbon capture and storage: SimCCS. Energy Policy 37 (3), 1052-1060.

MIT, 2010. MIT Clean Energy Prize. (Downloaded in September 2010 from 〈http:/ www.mitcep.org/ $>$ )

NASA, 2010. Centennial Challenges. Available at: <http://www.nasa.gov/offices/ ipp/innovation_incubator/centennial_challenges/beaming_tether/index.html $>$.

National Research Council, 2001. Energy Research at DOE: was it worth it?, Energy Efficiency and Fossil Energy Research 1978 to 2000. National Academy Press, Washington, DC., pp. 240. Available at $\langle$ http://www.nap.edu/catalog/10165. html>.

Newbery, D., Olmos, L., Ruester, S., Liong, S.J., Glachant, J.M., (2011). Public support for the financing of RD\&D activities in new clean energy technologies, A report published within the Framework Programme 7 project THINK. Available at: $\langle$ http://www.eui.eu/Projects/THINK/Documents/FinancingInnovation(v2).pdf $\rangle$.

Newell, R.G., Wilson, N.E., 2005. Technology prizes for climate change mitigation. Discussion Paper at Resources of the Future. (Downloaded in June 2010 from 〈http://www.rff.org/Publications/Pages/Technology-Prizes-for-Climate-Change-Mi tigation.aspx $>$.

Newell, R.G., 2007. Climate technology research, Development, and Demonstration: Funding Sources, Institutions and Instruments. (downloaded in May 2010 from 〈http://www.rff.org/Publications/Pages/CPF_Assessing USClimate PolicyOptions_IB9.aspx $>$ )

Pérez-Arriaga, I., Gómez, T., Olmos, L., Rivier, M., 2011. Transmission and distribution networks for a sustainable electricity supply. in: Handbook of Sustainable Energy. In: Markandya, A., Galarraga, I., González, M. (Eds.), Edward Edgar Publishing, Cheltenham, Reino Unido, pp. 2011.

Pérez-Arriaga, I.J., Rudnick, H., Rivier, M., 2008. Electric energy systems: an overview. In: Gomez-Exposito, A., Conejo, A.J., Cañizares, C. (Eds.), Electric Energy Systems: Analysis and Operation. , CRC Press, United Kingdom.

Popp, D., 2010. Innovation and climate policy. In: Gordon, C., Rausser, V., Smith, K. Zilberman, D. (Eds.), Annual Review of Resource Economics, 2. Annual Reviews, Palo Alto, CA, pp. 275-298.

Popp, D Newell, R.G. Jaffe A.B., 2009. Energy, the environment and technological change. NBER Working Paper no. 14832 Available at: $\langle$ http://www.nber.org papers/w14832.pdf $>$.

Popp, D., 2002. Induced innovation and energy prices. American Economic Review 92 (1), $160-180$

Reuters, 2010. US govt says loans for nuclear plants complicated (downloaded in November 2010 from <http://www.reuters.com/ article/idUSN1523562920100 $115>$ ).

Stoneman, P., 1987. The Economic Analysis of Technology Policy. Claredon Press, Oxford.

Vicente-Lorente, J.D., 2001. Specificity and opacity as resource-based determinants of capital structure: evidence for Spanish manufacturing firms. Strategic Management Journal 22, 157-177.

Wald, M.L., 2010. Aid sought for nuclear plants. In 'Green, a blog about energy and the environment. Available at: 〈http://green.blogs.nytimes.com/2010/09/23 aid-sought-for-nuclear-plants $/\rangle$

Wang, T., Thornhill, S., 2010. R\&D investment and financing choices: a comprehensive perspective. Research Policy 39 (9), 1148-1159.

Williamson, O.E., 1991. Strategizing, economizing and economic organization. Strategic Management Journal 12, 75-94. 